American Journal of Environmental Sciences 5 (1): 1-6, 2009

ISSN $1553-345 \mathrm{X}$

(C) 2009 Science Publications

\title{
Reducing the Environmental Impact of Olive Mill Wastewater
}

\author{
${ }^{1}$ Awni Khatib, ${ }^{1}$ Fathi Aqra, ${ }^{1}$ Nader Yaghi, ${ }^{1}$ Yousef Subuh, ${ }^{2}$ Bassam Hayeek, ${ }^{2}$ Mohammed Musa, ${ }^{3}$ Subhi \\ Basheer and ${ }^{3}$ Isam Sabbah \\ ${ }^{1}$ Department of Chemistry, Faculty of Science and Technology, Hebron University, \\ P.O. Box 40, Hebron, West Bank, Palestine \\ ${ }^{2}$ Environmental Research Center, Royal Scientific Society, Jordan \\ ${ }^{3} \mathrm{R}$ and D Center, the Galilee Society, P.O. Box 437, Shefa-Amr 20200, Israel
}

\begin{abstract}
Problem Statement: A research was needed to monitor the environmental impact of olive mill wastewater (OMW): production and relative production of olive mill waste. This was achieved by collecting data from 92 local olive mills in order to study the olive production yield, water consumption in olive washing and in oil recovery, wastewater generation relative to olive processed and oil generated, and solid waste generation. The OMW is usually discharged in the open environment, thus producing pollution to the soil surface and underground water. Approach: The progress on this problem is made by reducing the chemical oxygen demand (COD) as a major OMW pollutant. An upper flow anaerobic sludge bed (UASB) facility was constructed and operated for eight months in a progressive program operation for standardization and optimization purpose, and so to treat the waste by COD reduction. Results: The results reveal local variation in most of the investigated parameters. The olives in some area are found to contain large solid waste than other areas, resulting in lower oil yield and higher solid generation per ton of olive produced. The COD concentration was increased gradually from 5,000-30,000 mg/L and the efficiency improved significantly during the operation from $46 \%-84 \%$ COD removal. The organic load of OMW $27,000 \mathrm{mg} / \mathrm{L}$ was reduce below $5,000 \mathrm{mg} / \mathrm{L}$, that permits its direct discharge into municipal wastewater treatment plants. Conclusion: The implications and relevance of the results imply that OMW must be treated before discharge to the sewer system. On the other hand, the nonconformity between areas must be taken into consideration for future work.
\end{abstract}

Key words: Anaerobic treatment, biomass, olive mill wastewater, up flow anaerobic sludge blanket reactor

\section{INTRODUCTION}

Olive Mill Wastewater (OMW) generated by the process olive oil extraction is considered to be the main waste product of this industry. About $5.4 * 10^{6} \mathrm{~m}^{3} \mathrm{OMW}$ and $1.8 * 10^{6}$ tons of olive oil are annually produced worldwide $^{[1,2]}$. The uncontrolled disposal and treatment of OMW is a serious environmental problem because it contains high organic Chemical Oxygen Demand (COD) concentration and high content of microbial growth - inhibiting compound such as phenolic compound and tannins, and so resistance to degradation ${ }^{[3]}$. In addition, OMW contains polysaccharides, lipids, protein and aromatic molecules [4]. That inhibits anaerobic micro organism population.

The OMW is a significant source of environmental pollution ${ }^{[5]}$ because it is Negatively impacts the regional environment due to its toxicity to micro organisms in domestic wastewater treatment plants, its strong and unpleasant odour after anaerobic digestion, and its potential threat to surface and groundwater sources. It is often concentrated in evaporation ponds and left to dry throughout the summer season ${ }^{[6,7]}$, the seasonal production and high organic load of OMW make anaerobic treatment very reasonable ${ }^{[8]}$.

The improper disposal of OMW to the environment is prohibited due to its toxicity to micro organism and its potential threat to surface and groundwater. However, due to the lack of appropriate techniques for treatment of OMW, most of it is discharged into sewer system, water streams, or concentrated in cesspool. Therefore, it was considered worth while to develop a method for OMW treatment in a view to reduce its environmental impacts. This Study describes a

Corresponding Author: F. Aqra, Department of Chemistry, Faculty of Science and Technology, Hebron University, P.O. Box 40, Hebron, West Bank, Palestine 
technique for solving this problem via different anaerobic treatment system by using on upper flow anaerobic sludge blanket reactor (USAB) which is considered as one of the most popular bioreactors to treat agro-industrial wastewaters characterized with high organic load, because a very high efficiency of COD removal has been achieved using UASB reactors with an influent organic loading rate of $8 \mathrm{gCOD} /$ day $^{[9]}$. The major problems of UASB system are the long-term start-up period in addition to the instability of the biological activity as a result of washing out a significant part of the biomass from the reactor, the high toxicity of phenolic compounds, tannins, and adjusting the $\mathrm{pH}$ in the medium of the reactor ${ }^{[10]}$.

Suitable sludge source is highly important for both start-up period and overcoming the low biodegradability of toxic compounds typically present in OMW. Therefore, the main goal of this study is to examine the most suitable sludge to be used for OMW in anaerobic treatment systems, mainly UASB reactors.

\section{MATERIALS AND METHODS}

Pilot plant for the treatment of OMW: Pilot plant of $4 \mathrm{~m}^{3}$ in volume was designed and constructed for the treatment of OMW in one olive mill Hebron city. The concentration of COD in the reactor was $5000 \mathrm{~m} \mathrm{~L}^{-1}$. The amount of wastewater, which flowed into the reactor was $3 \mathrm{~m}^{3}$, and the amount of sludge seeded was $1900 \mathrm{~L}\left(1.9 \mathrm{~m}^{3}\right)$ with the concentration of $53 \mathrm{~g}$ VSS $\mathrm{L}^{-1}$. The constructed UASB was fed with diluted OMW with COD content in the range of 2000-5000 $\mathrm{mg} \mathrm{L}^{-1}$ during the start-up period of the continuous reactor. The generation of biogas bubbles in top of the reactor could be observed on the $5^{\text {th }}$ day of operation, indicating anaerobic activity. Anti-foaming agent was used to reduce the scum layer that periodically appeared on top of the liquid phase of the UASB reactor. The $\mathrm{pH}$ of the influent was adjusted to the range of 6.8-7.00 with alkaline solution while the $\mathrm{pH}$ of the effluent was in the range of 7.5-7.75. The COD applied after two weeks after start-up of the continuous reactor was $6250 \mathrm{mg}$ $\mathrm{L}^{-1}$, while the COD out was $1710 \mathrm{mg} \mathrm{L}^{-1}$ using a Hydraulic Retention Time (HRT) of 5 days. The flow rate was increased from around 980-1200 $\mathrm{L} \mathrm{d}^{-1}$ (HRT = 4.2 days) within a one-week period. Depending on the reactor performance the HRT has been decreased down to 3.5 days or less. The Study on the pilot station is being continued, with the aim of treating OMW in the constructed UASB system so that the effluents of the system can be disposed directly to the municipal wastewater system.

\section{RESULTS}

Properties of olive mill wastewater: Table1 summarizes the overall statistic information includes the number of mills, the total amounts of olive and olive oil produced in the West Bank and Gaza between the yr 1998 to 2002. From these data overall Percentage oil yield is estimated, which varies slightly from year to yr.

Table 1: The number of mills and total amounts of olive and olive oil produced in the West Bank and Gaza

\begin{tabular}{|c|c|c|c|c|c|}
\hline \multirow[t]{2}{*}{ Parameter } & \multicolumn{5}{|c|}{ Year } \\
\hline & 1998 & 1999 & 2000 & 2001 & 2002 \\
\hline $\begin{array}{l}\text { Number of } \\
\text { Mills }\end{array}$ & 227 & 165 & 249 & 194 & 246 \\
\hline $\begin{array}{l}\text { Amount of } \\
\text { Olive (Ton) }\end{array}$ & 64213 & 15092 & 126149 & 22154 & 124564 \\
\hline $\begin{array}{l}\text { Amount of } \\
\text { Oil (Ton) }\end{array}$ & 14998 & 3436 & 27062 & 5443 & 27744 \\
\hline $\begin{array}{l}\text { Oil Yield } \\
\text { (\%Oil/Olive) }\end{array}$ & $23.4 \%$ & $22.8 \%$ & $21.5 \%$ & $24.6 \%$ & $22.3 \%$ \\
\hline
\end{tabular}

Olive production data: Figure 1 shows the results of the conducted survey as plots of quantity of produced oil versus quantity of processed olive, for data from the cities Hebron, Nablus and Jenine. Obviously, the general trend is linear, and the slope represents the oil yield. Using linear curve fitting for the data provides the results summarized in Table 2.

The obtained fitting $\mathrm{R}^{2}$ values are almost above 0.99 . The oil yield from the data (\%Oil/Olive) has an average value of $23.7 \%$, which is consistent with the previous reports ${ }^{[12]}$, these results emphases, the fact that the oil yield in the south (Hebron) is lower than that in the north (Jenine and Nablus).

Figure 2 represents the obtained data of solid waste generation versus quantity of processed olive, in Hebron, Nablus and Jenine. Obviously, the general trend is linear, the slope which provides a representative value of the fraction of wet solid content in the fruits (fraction of solid waste). Using linear curve fitting for the data provides the results summarized in Table 3.

\section{DISCUSSION}

Extraction of oil is carried out by either continuous or discontinuous processes. That generate wastewater, with continuous process, (OMW) is $1.2-1.8 \mathrm{~m}^{-3}$ ton of olives, while with discontinuous process, it is only 0.4 $0.5 \mathrm{~m}^{3} /$ ton of olives ${ }^{[11,12]}$

The colour of wastewater produced is black to dark red due to the presence of phenolic compounds. The typical composition of OMW includes water $(83 \%)$, 
organic compounds $(15 \%)$, and inorganic chemicals (about 2\%). The organic load in OMW is considered one of the highest of all concentrated effluents, being 100-150 times higher than the organic load of domestic wastewater. OMW produced in discontinuous mills contains higher organic load than OMW generated in continuous mills. OMW is acidic, and contains high concentration of Total Suspended Solids (TSS), Total Dissolved Solids (TDS), phenols, and other organic matter. The organic content is characterized by high levels of Chemical Oxygen Demand (COD) and Biochemical Oxygen Demand (BOD), in addition to having a very high concentration of Fat, Oil, and Grease (FOG). No standards for OMW discharge or disposal are currently imposed in Palestine. The BOD and COD maximum concentrations in OMW reach 100,000 and $220,000 \mathrm{mg} \mathrm{L}^{-1}$, respectively. The majority of organic materials in OMW are sugars, tannins, polyphenols, polyalcohols, pectins, proteins, and lipids. Some of these compounds are toxic, and ecological stabilization and detoxification of their effects are expensive and ineffective ${ }^{[13,14]}$.

Currently, there is no appropriate method applied for treating OMW in Palestine; it is usually disposed of in sewage systems and/or cesspools in addition to being discharged into water streams and valleys in the region. That causes the disruption of biological activities in domestic wastewater ponds, creates a strong and unpleasant odour due to aerobic digestion in open air systems, and posses a threat to surface and groundwater $^{[15]}$. The disposal of OMW causes

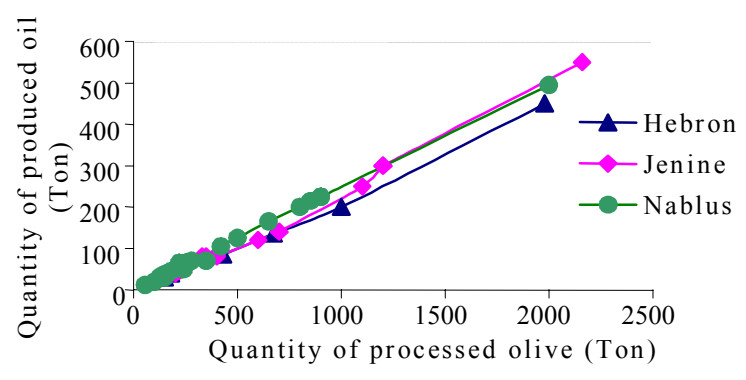

Fig. 1: Quantity of produced oil versus quantity of processed olive both in tons, for data from Hebron (triangles), Nablus (circles) and Jenine (diamonds)

Table 2: Results of linear curve fitting for oil production data obtained from the conducted survey

\begin{tabular}{llll}
\hline Local area & Fitting line & Fitting $\mathrm{R}^{2}$ & Oil yield (\%) \\
\hline Hebron & $\mathrm{Y}=0.219 \mathrm{X}$ & 0.9930 & $21.9 \%$ \\
Nablus & $\mathrm{Y}=0.248 \mathrm{X}$ & 0.9976 & $24.8 \%$ \\
Jenine & $\mathrm{Y}=0.243 \mathrm{X}$ & 0.9883 & $24.3 \%$ \\
All data as & $\mathrm{Y}=0.237 \mathrm{X}$ & 0.9926 & $23.7 \%$ \\
One plot (Average) & & & \\
\hline
\end{tabular}

serious environmental problems during the olive harvest season. In addition to wastewater generation, a large amount of solid waste is generated. This emphasizes the environmental concerns associated with olive oil production and highlights the need for this study.

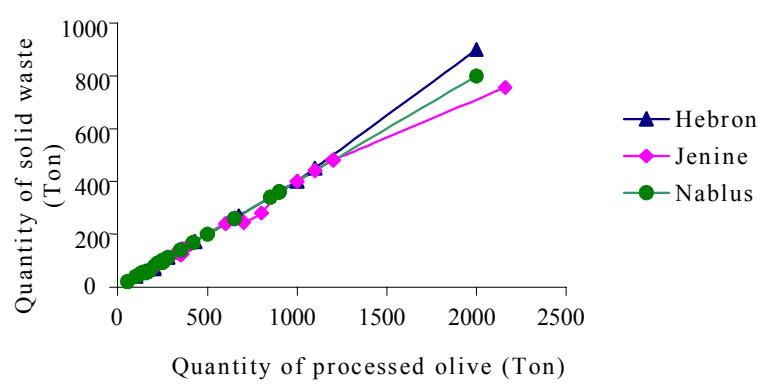

Fig. 2: Quantity of produced solid waste versus quantity of processed olive both in tons for data from Hebron (triangles), Nablus (circles) and Jenine (diamonds)

Table 3: Results of linear curve fitting for solid waste data obtained from the conducted survey

\begin{tabular}{llll}
\hline & & & $\begin{array}{l}\text { Fraction of } \\
\text { solid waste } \\
\text { in fruits }\end{array}$ \\
\hline Local area & Fitting line & Fitting $\mathrm{R}^{2}$ & 0.429 \\
Hebron & $\mathrm{Y}=0.429 \mathrm{X}$ & 0.9940 & 0.399 \\
Nablus & $\mathrm{Y}=0.399 \mathrm{X}$ & 0.9996 & 0.379 \\
$\begin{array}{l}\text { Jenine } \\
\text { All data as } \\
\text { one plot (Average) }\end{array}$ & $\mathrm{Y}=0.379 \mathrm{X}$ & 0.9868 & 0.403 \\
\hline
\end{tabular}

Similar to oil yield data, the obtained fitting $\mathrm{R}^{2}$ values are high (above 0.99) and so confirming Linearity. The fraction of solid waste (quantity of solid waste produced per quantity of processed olives) has an average value of 0.40 . Relatively, olive mills in Hebron area produce larger fraction of solid waste compared to those in the north areas. In olive mills, wastewater is generated via various sources such as water from olives and water used for processing. The latest source comes from two different steps; washing of olives and extraction of oil. The designed questionnaire enabled us to gather data for total wastewater, water used for washing and water used for extraction, which provided data for water consumption, while the difference between total wastewater and water consumption provided data for water produced from fruit.

Similar to oil yield data, the obtained fitting $\mathrm{R}^{2}$ values are high (above 0.99) and so confirming linearity. The fraction of solid waste (quantity of solid waste produced per quantity of processed olives) has an average value of 0.40 . Relatively, olive mills in Hebron area produce larger fraction of solid waste compared to those in the north areas. In olive mills, wastewater is 
generated via various sources such as water from olives and water used for processing. The latest source comes from two different steps; washing of olives and extraction of oil. The designed questionnaire enabled us to gather data for total wastewater, water used for washing and water used for extraction, which provided data for water consumption, while the difference between total wastewater and water consumption provided data for water produced from fruit.

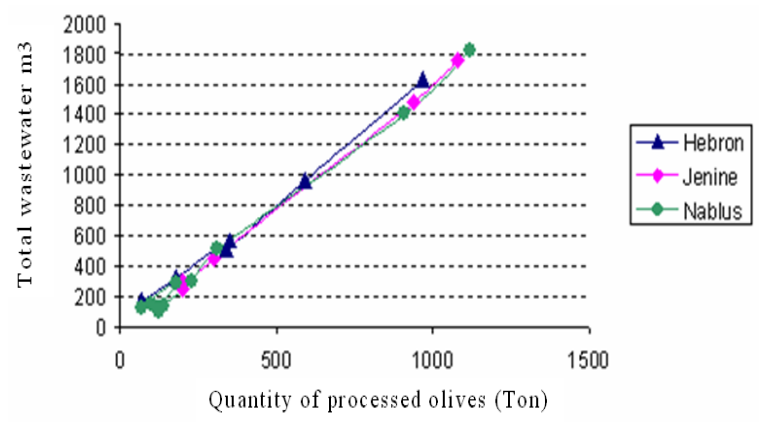

Fig. 3: Quantity of Total wastewater versus quantity of processed olive for data from Hebron (triangles), Nablus (circles) and Jenine (diamonds)

Table 4: Results of linear curve fitting for total wastewater data

\begin{tabular}{llll}
\hline Local Area & Fitting Line & Fitting $\mathrm{R}^{2}$ & $\begin{array}{l}\text { Total } \\
\text { wastewater }\end{array}$ \\
\hline Hebron & $\mathrm{Y}=1.656 \mathrm{X}$ & 0.9949 & 1.656 \\
Nablus & $\mathrm{Y}=1.573 \mathrm{X}$ & 0.9911 & 1.573 \\
Jenine & $\mathrm{Y}=1.551 \mathrm{X}$ & 0.9921 & 1.551 \\
$\begin{array}{l}\text { All data as } \\
\text { one plot (Average) }\end{array}$ & $\mathrm{Y}=1.593 \mathrm{X}$ & 0.9927 & 1.693 \\
\hline
\end{tabular}

Figure 3 represents plots of total wastewater (water from fruit, washing water and water for extraction) versus quantity of processed olives. The results of the linear curve fitting of these data are represented in
Table 4. The slopes provide the ratio of total wastewater generated from olive mills per quantity of processed olives. The average value is nearly $1.7 \mathrm{~m}^{3}$ Wastewater/ton olives. Which is within the reported range of $1.2-1.8 \mathrm{~m}^{3} /$ ton of OMW for continuous processes. However, the average value of the volume of OMW in Palestine fits within the range for continuous processes (which generates almost three times more wastewater than discontinuous processes). Consequently, it is important to perform technical review for the implemented technology and procedures to reduce the rate of wastewater generation.

The results of the experimental Study for the obtained typical characteristics of olive mills wastewater are tabulated in Table 5. The obtained values at three intervals (beginning, middle and end of the harvest season) are listed and compared to the Jordanian standards for OMW for discharge to sanitary systems (Table 1).

These results indicate that there are some variations from time to time during the season. However, the investigation of these variations requires more extensive analysis and larger amount of data which is the subject of a subsequent Study by the authors. At present the average values for the investigated characteristic parameters are considered. Obviously, other than the $\mathrm{pH}$-value, other comparable values are all above the permitted values and thus the discharge of such OMW violates these standards and shall receive sufficient attention from authorities to encounter the environmental problem. Currently we demonstrate the applicability of Upper Flow Anaerobic Sludge Blanket for minimizing the environmental impacts of OMW. A pilot plant is established for this purpose (Fig. 4) and the data obtained from the pilot plant are given in table 6 this data as a function of time resulted in Fig. 5.
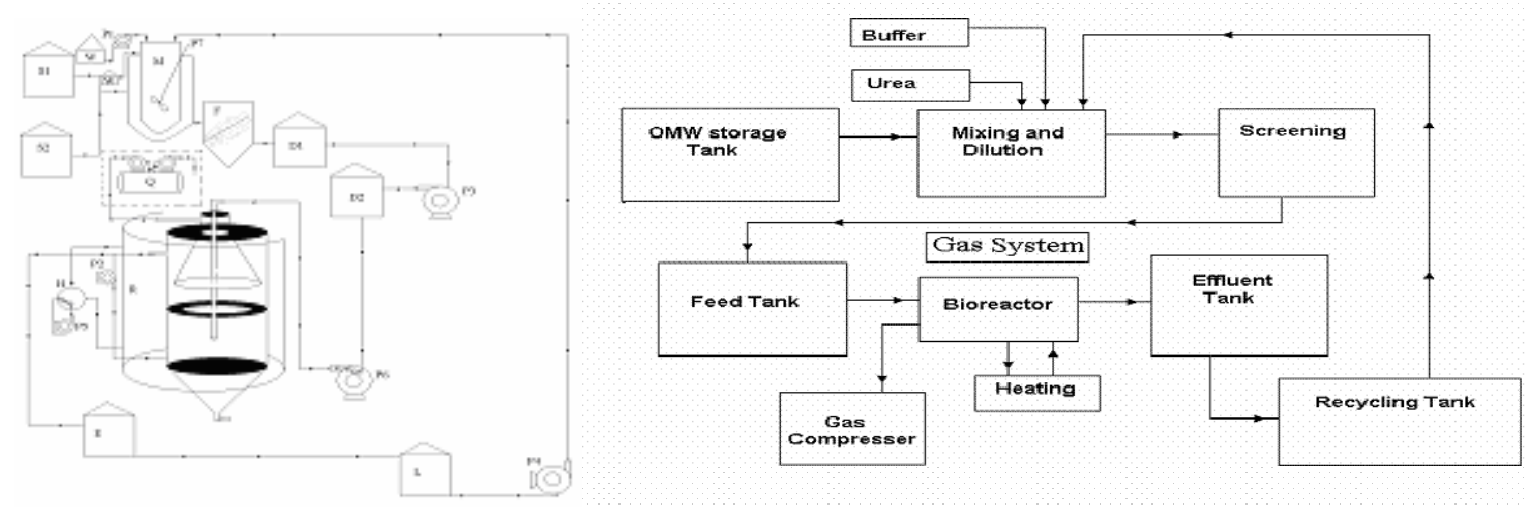

Fig. 4: Flow scheme diagram for the constructed UASB Plant in Hebron 
Am. J. Environ. Sci., 5 (1): 1-6, 2009

Table 5: Experimental results of OMW characteristics in Palestine for sample obtained at the beginning, middle and end of harvest season

\begin{tabular}{|c|c|c|c|c|c|c|}
\hline \multirow[b]{2}{*}{ Parameter } & \multirow[b]{2}{*}{ Unit } & \multicolumn{3}{|c|}{ Value } & \multirow[b]{2}{*}{ Average } & \multirow{2}{*}{$\begin{array}{l}\text { Maximum Allowable Limit- } \\
\text { Jordanian standards } \\
\text { (Discharge to sanitary systems) }\end{array}$} \\
\hline & & Beginning & Middle & End & & \\
\hline $\mathrm{pH}$ & SU & 4.8 & 5.08 & 5.1 & 4.99 & $5.5-9.5$ \\
\hline COD & $\mathrm{Mg} \mathrm{L}^{-1}$ & 88535 & 98882 & 109582 & 98999.67 & 1100 \\
\hline $\mathrm{BOD}_{5}$ & $\mathrm{Mg} \mathrm{L}^{-1}$ & 42667 & 45680 & 48527 & 45624.67 & 2100 \\
\hline TSS & $\mathrm{Mg} \mathrm{L}^{-1}$ & 11271 & 17335 & 22285 & 16963.67 & 800 \\
\hline TDS & $\mathrm{Mg} \mathrm{L}^{-1}$ & 39063 & 27437 & 39138 & 35212.67 & \\
\hline FOG & $\mathrm{Mg} \mathrm{L}^{-1}$ & 3361 & 3363 & 4466 & 3730 & 50 \\
\hline Phenol & $\mathrm{Mg} \mathrm{L}^{-1}$ & 3057 & 3087 & 3304 & 3149.33 & 10 \\
\hline$* \mathrm{EC}$ & $\mu \mathrm{s} / \mathrm{cm}$ & 7121 & 6190 & 6815 & 6708.67 & \\
\hline$* * \mathrm{~T}-\mathrm{P}$ & $\mathrm{Mg} \mathrm{L}^{-1}$ & 287 & 198 & 228 & 237.67 & \\
\hline$* * *$ Tkj-N & $\mathrm{Mg} \mathrm{L}^{-1}$ & 648 & 348 & 587 & 527.67 & \\
\hline
\end{tabular}

* EC Electric Conductivity, ${ }^{* *}$ T-P Total Phosphorus, ${ }^{* * *}$ Tkj-N $\quad$ Total Kejndal nitrogen

Table 6: Data of pilot plant

\begin{tabular}{lll}
\hline Date & COD in & COD out \\
\hline 29-May.04 & 6250 & 3390 \\
10-Jun-04 & 6250 & 1725 \\
20-Jun-04 & 8150 & 1100 \\
28-Jun-04 & 7963 & 1354 \\
5-Jul-04 & 7500 & 1980 \\
20-Jul-04 & 9980 & 3250 \\
1-Aug-04 & 10150 & 3648 \\
15-Aug-04 & 9500 & 2550 \\
28-Aug-04 & 14700 & 4580 \\
9-Sep-04 & 15300 & 5100 \\
23-Sep-04 & 15400 & 2425 \\
7-Oct-04 & 15300 & 2628 \\
23-Oct-04 & 18450 & 2800 \\
1-Nov-04 & 19870 & 3190 \\
15-Nov-04 & 24220 & 3421 \\
17-Dec-04 & 27140 & 4520 \\
5-Jan-05 & 27320 & 4372 \\
\hline
\end{tabular}

COD in and COD out as a function of time(days)

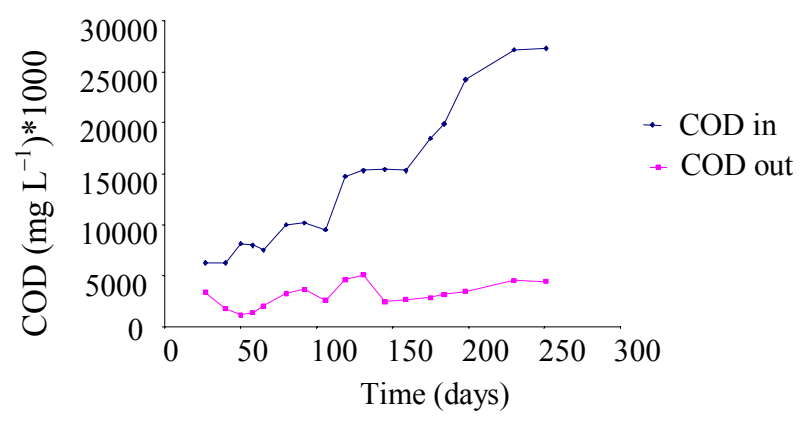

Fig. 5: The COD in concentration $\left(\mathrm{mg} \mathrm{L}^{1}\right)$ and COD out as a function of time in a UASB reactor. Experimental conditions: Organic loading rate was $12 \mathrm{~g} \mathrm{~L}^{1}$.day, temperature of $35^{\circ} \mathrm{C}$, and $\mathrm{pH}$ of 7 , UASB reactor volume $5 \mathrm{~m}^{3}$.

\section{CONCLUSION}

This Study highlights the environmental concerns associated with olive oil production. The conducted survey reveals that there are local variations in the investigated parameters due to variations in the types of olives. Oil and water content in olives are dependent on location. The olives in the south are found to contain larger solid content than those in the north, resulting in lower oil yield and higher solid generation per ton of olive produced. The oil yield is nearly $23.7 \%$, the fractional solid waste generation is nearly 0.4 while the remaining balance is nearly the water content in the olive fruit.

A representative value of $1.7 \mathrm{~m}^{3} \mathrm{OMW} /$ ton olives for wastewater generation is found and considered too high compared to values in other places of the world which requires technical review at the technology and operation of olive mills. The characteristics of OMW far exceed the standards for OMW disposal which requires the attention of authorities.

It was shown that $84 \%$ of COD removal was achieved using UASB technology under the specified parameters. This COD removal makes the OMW within the OMW disposal standards. Biogas (mainly methane) was collected and used.

\section{ACKNOWLEDGEMENT}

The authors wish to thank USAID for financial support of this research [grant No. TA-MOU-00- M20-00-091]. 


\section{REFERENCES}

1. Benitez, F.J., J. Beltran-Heredia, J. Torregrosa and J.L. Acero, 1997a. Aerobic degradation of olive mill wastewater. Appl. Microbiol. Biotechnol., 47: 185-188.

http://www.ncbi.nlm.nih.gov/pubmed/9077005

2. Baccari, M., F. Bonemazzi, M. Majone and C. Riccardi, 1996. Interaction between acidogenesis and methanogenesis in the anaerobic treatment of olive oil mill effluents. Wat. Res., 30: 183-189. Doi: 10.1016/0043-1354(95)00086-Z

3. Ramos-Comenzana, A., M. Monteolica-Sanchez and M.J. Lopez, 1995. Bioremediation of alpechin. J. Biodeter. Biodegr., 35: 249-268. Doi: 10.1016/0964-8305(95)00033-2.

4. Ethaliotis, C., K. Papadopoulou, M. Kotsou, I. Mari and C. Balis, 1999. Adaptation and population dynamics of Aztobacter vinelandii during aerobic biological treatment of olive mill wastewater. FEMS Microbiol. Ecol., 30: 301-311. Doi: 10.1111/j.1574-6941.1999.tb00658.x

5. Basheer, S., I. Sabbah and T. Marzook, 2004. The effect of pre-treatment on anaerobic activity of olive mill wastewater using batch and continuous systems. Process Biochem., 39: 1947- 1951. Doi: 10.1016/j.procbio.2003.09.026

6. Borja, R., M. Martin, R. Maestro, J. Alba and J.A. Fiestas, 1992. Enhancement of the anaerobic digestion of olive mill wastewater by the removal of phenolic inhibitors. Process Biochem., 27: 231237.

7. Benitez, F.J., J. Beltran-Heredia, J. Torregrosa, J.L. Acero and V. Cercas,1997b. Chemical pretreatment by ozone of wastewater from olive oil mills. Technol. Environ. Chem., 60: 97-109. http://md1.csa.com/partners/viewrecord.php?reque ster $=$ gs\&collection $=$ ENV\&recid $=4431507 \& q=$ Che mical + pretreatment + by + ozone + of + wastewater + fro $\mathrm{m}+$ olive + oil + mills\&uid $=\&$ setcookie $=$ yes
8. Boari, G., A. Brunetti, R. Passino and A. Rozzi, 1984. Anaerobic digestion of olive mill wastewater. Agri. Wastes, 10: 161-175. http://cat.inist.fr/?aModele $=$ afficheN\&cpsidt $=9602$ 459

9. Erguder, T.H., E. Guven and Demirer, 2000. Anaerobic treatment of olive mill wastes in batch reactors. Process Biochem., 36: 243-248. DOI: 10.1016/S0032-9592(00)00205-3

10. Sabbah, I., T. Marzook and S. Basheer, 2004. The effect of pre-treatment on anaerobic activity of olive mill wastewater using batch and continuous systems. Process Biochem., 39: 1947-1951. Doi:10.1016/j.procbio.2003.09.026

11. Tomati, U. and E. Galli, 1992. The fertilizing value of wastewater from the olive processing industry. Dev Agric. Manage. Ecol., 25: 117-126. http://www.fao.org/agris/search/display.do?f=./199 2/v1814/NL9204762.xml;NL9204762

12. Vlyssides, A.G., M. Loizidou, K. Gimouhopoulos and A. Zorpas, 1998. Olive oil processing waste production and their characterizing in relation to olive oil extraction methods. Fresenius Envir. Bull., 7: 308-313.

13. Borja, R., A. Martin, R. Maestro, J. Alba and J.A. Fiestas, 1992. Enhancement of the anaerobic digestion of olive mill wastewater by the removal of phenolic inhibitors. Process Biochem., 27: 231237.

14. Borja, R., V. Martin, V. Alonso, I. Garcia and C.J. Banks,1995. Influence of different aerobic pretreatments on the kinetics of anaerobic digestion of olive mill wastewater. Water Res., 28: 489-495. Doi: 10.1016/0043-1354(94)00180-F

15. Hamdi, M., 1992. Toxicity and biodegradability of olive mill wastewater on batch anaerobic digestion. Applied Biochem. Biotechnol., 37: 155-163. DOI: 10.1007/BF02921667 